\title{
UWARUNKOWANIA ROZWOJU PRZEDSIĘBIORSTW ROLNYCH NASTAWIONYCH NA PRODUKCJĘ ZWIERZECAC W WARUNKACH KONKURENCJI I GLOBALIZACJI
}

\author{
Wojciech Ziętara
}

Zakład Ekonomiki Gospodarstw Rolnych IERiGŻ-PIB w Warszawie Kierownik zakładu: prof. dr hab. Wojciech Józwiak

\begin{abstract}
Słowa kluczowe: gospodarstwa i przedsiębiorstwa rolnicze, bariery rozwoju, efektywność gospodarowania, konkurencyjność

Key words: farms and agricultural companies, barriers to their development, economic efficiency, competitiveness

S y n o p s i s. W opracowaniu przedstawiono ekonomiczne, społeczne, środowiskowe i administracyjne uwarunkowania rozwoju przedsiębiorstw rolnych, głównie z chowem trzody chlewnej i bydła. Wskazano czynniki ekonomiczne i organizacyjne skłaniające przedsiębiorstwa rolne do zwiększania skali produkcji. Czynniki ekonomiczne związane są z szybszym tempem wzrostu kosztów pracy w gospodarce narodowej i cen środków produkcji rolniczej od cen zbytu produktów rolnych. Czynniki organizacyjne wiążą się z rosnącymi wymogami przedsiębiorstw handlu i przetwórstwa rolnego w zakresie wielkości, jakości i terminowości dostaw. Wzrost skali produkcji w gospodarstwach może prowadzić do nadmiernego obciążenia środowiska i wzrostu uciążliwości z powodu odorów dla ludności na terenach wiejskich i w efekcie do sytuacji konfliktowych na tle społecznym. Ponadto występują bariery administracyjne utrudniające realizację inwestycji budowlanych związanych z rozwojem produkcji zwierzęcej.
\end{abstract}

\section{WSTĘP}

Otwarta gospodarka rynkowa w znaczący sposób przyczyniła się do intensywnego rozwoju kontaktów handlowych, nie tylko między krajami danego kontynentu, lecz także między kontynentami. Istotną rolę w handlu międzynarodowym odgrywa Światowa Organizacja Handlu (WTO), która dąży do ograniczania i likwidacji barier w handlu, w tym szczególnie produktami rolniczymi i ich przetworami. Koszty produkcji tych produktów zależą nie tylko od kosztów pracy i kapitału, lecz także od warunków przyrodniczych (gleby i klimatu). Ograniczanie barier w handlu międzynarodowym przy jednoczesnym postępie technicznym, skutkującym obniżeniem kosztów transportu umożliwiło prowadzenie produkcji rolniczej w rejonach o najkorzystniejszych warunkach glebowych i klimatycznych zapewniających niższe koszty produkcji. Przykładem może być produkcja warzyw i kwiatów w uprawie polowej w Afryce Północnej z wykorzystaniem energii słonecznej zamiast przy wysokich nakładach energii w szklarniach w Europie Północnej w okresie jesienno-zimowym. Te zjawiska umożliwiły ekwiwalentną wymianę handlową między krajami z różnych kontynentów, przy jednoczesnym nasileniu konkurencji międzynarodowej. 
Na rynkach międzynarodowych nie konkurują bezpośrednio przedsiębiorstwa i gospodarstwa rolnicze ${ }^{1}$, lecz przedsiębiorstwa handlowe i przetwórstwa rolniczego. Ich efektywność w znaczącym stopniu zależy od kosztów surowców rolniczych wytwarzanych w przedsiębiorstwach rolniczych ${ }^{2}$. Z tego powodu efektywność produkcji w przedsiębiorstwach rolniczych jest istotnym czynnikiem wpływającym na sprawność działalności przedsiębiorstw handlu i przetwórstwa. Przedsiębiorstwa te w celu obniżania kosztów swojego funkcjonowania żądają od swoich dostawców ciągłości dostaw surowców o odpowiedniej skali i jakości. Wymogi te zmuszają przedsiębiorstwa rolnicze do ciągłego doskonalenia procesów produkcyjnych i do powiększania skali produkcji.

Oprócz wyżej wymienionych czynników organizacyjnych związanych z rynkiem, skłaniających przedsiębiorstwa rolnicze do zwiększania skali produkcji, istotną rolę odgrywają także czynniki ekonomiczne związane z różnym tempem wzrostu kosztów pracy w gospodarce narodowej, cen środków do produkcji rolnej i cen zbytu produktów rolniczych. Ilustracją tych tendencji jest rysunek 1, z którego danych wynika, że w okresie 1996-2015 najbardziej wzrosły (ponadpięciokrotnie) koszty pracy w gospodarce narodowej, w których głównym składnikiem były wynagrodzenia. Wzrost kosztów pracy w gospodarce narodowej poza rolnictwem determinuje koszty pracy w rolnictwie i wpływa na subiektywne postrzeganie sytuacji dochodowej rolników. W tym samym okresie koszty (ceny) środków do produkcji rolniczej wzrosły ponadtrzykrotnie, a ceny produktów rolniczych zbywanych przez rolników wzrosły ponaddwukrotnie. Różne tempo wzrostu cen środ-

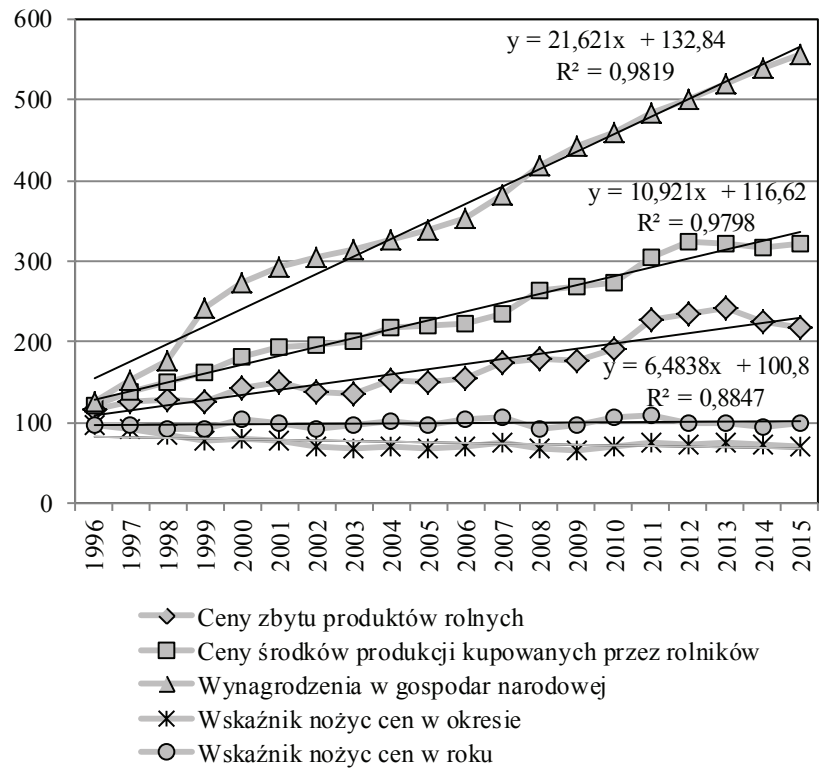

Rysunek 1. Tendencje zmian kosztów i cen produktów rolnych Źródło: zestawienie własne na podstawie danych statystycznych GUS za lata 1996-2015.

1 Gospodarstwa rolnicze, w tym indywidualne o charakterze towarowym, mają charakter przedsiębiorstw osoby fizycznej. Z tego powodu w dalszych częściach opracowania stosowane będzie pojęcie ,przedsiębiorstwo rolnicze", obejmujące różne formy prawne.

2 Według Augustyna Wosia w przedsiębiorstwach przetwórstwa rolniczego udział kosztów surowca w całkowitych kosztach wynosi około 70\% [Woś 2003], podobne zależności występują w przedsiębiorstwach handlu produktami rolnictwa. 
ków produkcji i cen produktów rolnych spowodowało spadek jednostkowej opłacalności produkcji rolniczej. Informuje o tym wskaźnik nożyc cen, który w analizowanym okresie obniżył się do $70 \%$. Oznacza to, że tempo wzrostu cen środków do produkcji rolniczej było o $30 \%$ wyższe od tempa wzrostu cen zbytu produktów rolnych. Obniżenie jednostkowej opłacalności produkcji zmusza rolników do zwiększania skali produkcji w celu osiągnięcia satysfakcjonującego poziomu dochodu z gospodarstwa.

Biorąc pod uwagę wyżej wymienione przesłanki zwiększania skali produkcji w przedsiębiorstwach rolniczych, należy określić czynniki determinujące rozwój przedsiębiorstw rolnych w Polsce.

\section{CEL BADAŃ, ŹRÓDŁA MATERIAŁÓW I METODY}

Celem badań było przedstawienie i ocena ekonomicznych, społecznych i środowiskowych uwarunkowań rozwoju przedsiębiorstw rolnych w Polsce w warunkach konkurencji i globalizacji. Realizując tak nakreślony cel badań, przyjęto następujące założenia:

1) dążenie rolnika do osiągania satysfakcjonującego dochodu z gospodarstwa wiąże się głównie ze wzrostem skali produkcji w gospodarstwie;

2) Wzrost skali produkcji prowadzi do zwiększania wielkości gospodarstw (według powierzchni i wielkości ekonomicznej ${ }^{3}$ ) i tym samym do sytuacji konfliktowej na terenach wiejskich w następujących obszarach: zwiększanie wielkości gospodarstw rolnych następuje kosztem wypadania innych gospodarstw bez zdolności rozwojowych, spadek liczby aktywnych gospodarstw rolnych i napływ ludności nierolniczej na tereny wiejskie zmienia relacje ludności rolniczej do nierolniczej i stwarza groźbę konfliktów, wzrost skali produkcji zwierzęcej w gospodarstwach rolnych zwiększa prawdopodobieństwo zagrożeń środowiskowych.

Przyjmując te założenia scharakteryzowano następujące zagadnienia: zmiany wielkości gospodarstw w Polsce i w wybranych krajach, zmiany poziomu koncentracji chowu bydła i trzody chlewnej w Polsce i wybranych krajach, określenie minimalnych wielkości polskich gospodarstw zdolnych do konkurencji i konkurencyjnych. Przyjęto jednocześnie następującą hipotezę badawczą: integrowany system produkcji rolniczej oparty na wiedzy umożliwia uzyskanie w gospodarstwie rolniczym równowagi między celami ekonomicznymi, społecznymi i środowiskowymi.

Podstawowym źródłem materiałów badawczych były dane statystyczne, dane z gospodarstw objętych systemem rachunkowości FADN ${ }^{4}$ i literatura przedmiotu. W badaniach posłużono się metodą opisową i porównawczą. Zagadnienia dotyczące polskich gospodarstw przedstawiono na tle wybranych krajów Unii Europejskiej (UE): Danii, Francji, Holandii, Niemiec, Szwecji, Wielkiej Brytanii, Czech, Słowacji i Węgier. Okres badań był zróżnicowany w zależności od rozpatrywanego zagadnienia. Najdłuższy, gdyż od 1960 roku do 2013, dotyczył tendencji w zakresie zmian wielkości gospodarstw. Szczegółowszą analizą objęto gospodarstwa $\mathrm{z}$ chowem bydła i trzody chlewnej, w których to grupach wystąpiły największe zagrożenia, natomiast pominięto producentów drobiu z uwagi na ich dobrą sytuację ekonomiczną.

3 Tradycyjną miarą wielkości gospodarstw jest powierzchnia użytków rolnych wyrażona w ha, natomiast wielkość ekonomiczna wyrażana jest wartością standardowej produkcji (ang. SO - Standard Output) wyrażonej w tys. euro.

$4 \quad$ FADN - ang. Farm Accountancy Data Network. 
Konkurencyjność gospodarstw określono wskaźnikiem konkurencyjności $(W k)$ za Wernerem Kleinhanssem [Kleinhanss 2015]:

$$
W k=\frac{D z g r}{K w z+K w p+K w k}
$$

gdzie: Wk - wskaźnik konkurencyjności, Dzgr - dochód z gospodarstwa rolnego, $K w z$ - koszt alternatywny własnej ziemi, $K w p$ - koszt alternatywny własnej pracy, $K w k$ - koszt alternatywny własnego kapitału (bez własnej ziemi).

Wskaźnik konkurencyjności (krotność) ustalono jako iloraz dochodu z gospodarstwa rolnego oraz sumy szacunkowo określonych kosztów użycia własnych czynników produkcji: pracy, ziemi i kapitału. Przyjęto za W. Kleinhanssem dalszą klasyfikację $W k$, wyróżniając następujące klasy: $W k(-)$ - w przypadku ujemnego Dzgr (Wk1), $0<W k<1$ - częściowe pokrycie kosztów własnych czynników produkcji (Wk2), $1=W k<2-$ pełne pokrycie kosztów własnych czynników produkcji $(W k 3)$, $W k \geq 2$ - dwukrotne i większe pokrycie kosztów własnych czynników produkcji ( $W k 4)$. Wskaźnik $W k 3$ wskazuje na zdolności gospodarstwa do konkurencji (do rozwoju), natomiast $W k 4$ wskazuje na konkurencyjność. Stwierdzenie to jest zbieżne z poglądem Hansa Christopha Biswangera, który wskazał, że przedsiębiorstwo zdolne to rozwoju powinno osiągać stopę zysku dwukrotnie wyższą od oprocentowania kredytów [Biswanger 2011].

\section{ZMIANY WIELKOŚCI GOSPODARSTW I STAD ZWIERZĄT W POLSCE I W WYBRANYCH KRAJACH}

Liczby charakteryzujące zmiany powierzchni gospodarstw w badanych krajach przedstawiono w tabeli 1. W 1960 roku powierzchnia gospodarstw zawarta była w przedziale od 5,9 ha (Polska) do 41 ha UR (Wlk. Brytania). W pozostałych krajach wynosiła od 7,9 do 15,8 ha. W 2013 roku w krajach Europy Zachodniej powierzchnia gospodarstw zawarta była w przedziale od 27,4 ha (Holandia) do 93,6 ha (Wlk. Brytania). W analizowanym okresie powierzchnia gospodarstw w tych krajach wzrosła od 2,28 (Wlk. Brytania) do 7,41 razy (Niemcy). Mniejsza powierzchnia gospodarstw w Holandii w stosunku do sąsiednich krajów jest rekompensowana wysokim poziomem intensywności produkcji, który spowodował, że pod względem wielkości ekonomicznej gospodarstwa holenderskie były zbliżone do brytyjskich, mimo że te ostatnie użytkowały trzykrotnie większą powierzchnię.

Tabela 1. Zmiany powierzchni gospodarstw w badanych krajach

\begin{tabular}{lrrrrr}
\hline Kraje & \multicolumn{3}{c}{ Średnia powierzchnia w ha użytków rolnych (UR) w roku } & Wskaźnik \\
\cline { 2 - 4 } & 1960 & 1970 & 1990 & 2013 & $1960=100$ \\
\hline Dania & 15,8 & 21,0 & 34,2 & 62,9 & 398,1 \\
Francja & 17,8 & 10,0 &. & 58,7 & 329,8 \\
Holandia & 7,9 & 12,8 & 16,1 & 27,4 & 346,8 \\
Niemcy & 7,9 & 10,3 & 26,1 & 58,6 & 741,7 \\
Szwecja & 14,1 & 17,8 &. & 45,2 & 320,6 \\
Wlk. Brytania & 41,0 & 57,0 & 67,9 & 93,6 & 228,3 \\
Polska & 5,9 & 5,1 & 6,3 & 10,1 & 171,0 \\
\hline
\end{tabular}

Źródło: [Statistisches Jahrbuch über Ernährung 2015]. 
Powierzchnia gospodarstw polskich w 1960 roku wynosiła 5,9 ha i była o $25 \%$ mniejsza niż niemieckich, a w 2013 roku wzrosła do 10,1 ha i była mniejsza od gospodarstw niemieckich o $83 \%$. Podane liczby wskazują na olbrzymi dystans, który dzieli polskie gospodarstwa od gospodarstw analizowanych krajów.

Wzrost średniej powierzchni gospodarstw wiązał się ze spadkiem ich liczby we wszystkich analizowanych krajach, w tym także w Polsce. W tabeli 2. przedstawiono zmiany w liczbie gospodarstw z chowem bydła w Polsce w latach 1996-2013. W tym okresie liczba gospodarstw z chowem bydła zmniejszyła się o $69 \%$, a gospodarstw mlecznych o $73 \%$. W roku 1996 było 1309 tys. gospodarstw mlecznych, a w 2013 roku 357 tys. Skutkiem spadku liczby gospodarstw utrzymujących krowy mleczne był wzrost średniej wielkości stada krów z 2,6 w 1996 roku do 6,8 sztuk w 2013 roku.

Tabela 2. Liczba gospodarstw i pogłowie krów w Polsce w latach 1996-2013

\begin{tabular}{lrrrrrr}
\hline Wyszczególnienie & 1996 & 2002 & 2004 & 2008 & 2010 & 2013 \\
\hline Liczba gospodarstw utrzymujących bydło & 1374 & 936 & 784 & 718 & 526 & 424 \\
Liczba gospodarstw utrzymujących krowy & 1309 & 875 & 730 & 657 & 454 & 357 \\
Pogłowie bydła & 6997 & 5538 & 5353 & 5757 & 5761 & 5589 \\
Pogłowie krów & 3461 & 2873 & 2796 & 2807 & 2650 & 2442 \\
\hline
\end{tabular}

Źródło: [GUS 2014, 2015b, Ziętara i in. 2013].

Proces koncentracji w gospodarstwach mlecznych odbył się szczególnie po wejściu Polski do UE w 2004 roku, gdy polskie rolnictwo zostało objęte wspólną polityką rolną. Producentom mleka przyznane zostały kwoty mleczne. Jednocześnie polskie przetwórstwo mleka musiało dostosować się do wymagań jakościowych obowiązujących w UE. Przedsiębiorstwa zajmujące się skupem i przetwórstwem mleka (spółdzielnie mleczarskie i inne podmioty, głównie spółki z o.o.) zwiększyły wymagania jakościowe skupowanego mleka. Spowodowało to eliminację z rynku drobnych producentów, którzy nie byli w stanie sprostać wymogom jakościowym. Według stanu na 31 marca 2003 roku, liczba dostawców hurtowych, którym przyznano kwoty mleczne, wynosiła 355 tys. Średnia liczba krów w gospodarstwie dostawcy wynosiła około 6 sztuk. Na koniec roku kwotowego 2014/2015 liczba dostawców hurtowych wynosiła 130,8 tys. i była o 63\% mniejsza niż w 2003 roku, a liczba krów w gospodarstwie wzrosła do 14 sztuk [Ziętara, Adamski 2016].

Wystąpiły również istotne zmiany w obsadzie krów w przeliczeniu na 100 ha UR. Średnia obsada krów w 1990 roku wynosiła 26,3 krów, natomiast w 2013 roku tylko 17 krów. Spadek w obsadzie wynosił 35,4\%. Najwyższy spadek obsady krów wystąpił w województwach małopolskim, podkarpackim i świętokrzyskim, odpowiednio z: 42,4; 34,9 i 32,8 krowy w 1990 roku do 16,4; 9,9 i 12,9 w 2013 roku. Najwyższa obsada krów w 2013 roku wystąpiła w województwach: podlaskim, warmińsko-mazurskim i łódzkim, gdzie wynosiła odpowiednio: 42; 20,2 i 19,3 krowy w przeliczeniu na 100 ha UR. Najniższa obsada krów wystąpiła w województwach: dolnośląskim i zachodniopomorskim, gdzie wynosiła 4,0 i 4,7 krowy na 100 ha UR [Ziętara, Adamski 2016].

Mimo postępującej koncentracji w chowie bydła w Polsce występuje bardzo duży dystans w tym zakresie w stosunku do krajów Europy Zachodniej. Odpowiednie liczby przedstawiono w tabeli 3 . We wszystkich krajach nastąpiło zwiększenie liczebności stad bydła i krów. Pogłowie bydła w latach 2005-2013 wzrosło w Polsce średnio o 57\%, natomiast w pozostałych krajach średnio o około 30\%. Zwiększenie stad krów było silnie zróżnicowane. Najbardziej 
Tabela 3. Zmiany wielkości stad bydła i krów w badanych krajach w latach 2005-2013

\begin{tabular}{lccccc}
\hline Kraje & \multicolumn{2}{c}{ Bydło [szt.] } & \multicolumn{2}{c}{ Krowy [szt.] } & Wskaźnik \\
\cline { 2 - 5 } & 2005 & 2013 & 2005 & 2013 & $2005=100$ \\
\hline Dania & 93 & 129 & 85 & 128 & $139 / 151$ \\
Francja & 80 & 105 & 37 & 40 & $131 / 108$ \\
Holandia & 102 & 132 & 61 & 83 & $129 / 136$ \\
Niemcy & 71 & 95 & 38 & 54 & $134 / 142$ \\
Szwecja & 61 & 72 & 46 & 74 & $129 / 161$ \\
Wlk. Brytania & 96 & 79 & 46 & 74 & $122 / 106$ \\
Polska & 7 & 11 & 4 & 7 & $157 / 175$ \\
\hline
\end{tabular}

Źródło: jak w tab. 1.

wzrosło w gospodarstwach polskich (aż o 75\%), natomiast w pozostałych krajach od 6 i $8 \%$ w Wlk. Brytanii i Francji, do 51\% w gospodarstwach duńskich.

Odnotowano bardzo duży dystans między średnią wielkością stada bydła w Polsce i w pozostałych krajach. W 2005 roku średnia wielkość stada bydła w polskich gospodarstwach wynosiła 7 sztuk, a w pozostałych krajach zawarta była w przedziale od 61 sztuk (Szwecja) do 102 sztuk (Holandia) i była odpowiednio 9 i 14,5 razy większa. W 2013 roku średnia wielkość stada bydła w gospodarstwach polskich wynosiła 11 sztuk. W pozostałych krajach była od 7 do 12 razy większa. Zdecydowanie większe różnice wystąpiły w wielkości stad krów. W 2005 roku średnio w gospodarstwach polskich utrzymywano 4 krowy, natomiast w pozostałych krajach od 37 sztuk (Francja) do 85 sztuk ( Dania). Było to odpowiednio 9,5 i 18,3 razy więcej. W 2013 roku różnice były mniejsze. W polskich gospodarstwach średnio utrzymywano 7 krów, natomiast w pozostałych krajach od 40 sztuk (Francja) do 128 sztuk (Dania). Przedstawione liczby wskazują na postępujący proces koncentracji w chowie bydła, będący efektem procesów dostosowawczych w sytuacji obniżającej się jednostkowej opłacalności produkcji rolniczej.

Podobne procesy wystąpiły w chowie trzody chlewnej. Na rysunku 2. przedstawiono zmiany w pogłowiu trzody chlewnej w Polsce w latach 1993-2016. Wynika z niego, że w latach 1993-2007 pogłowie trzody chlewnej utrzymywało się na poziomie około $18 \mathrm{mln}$

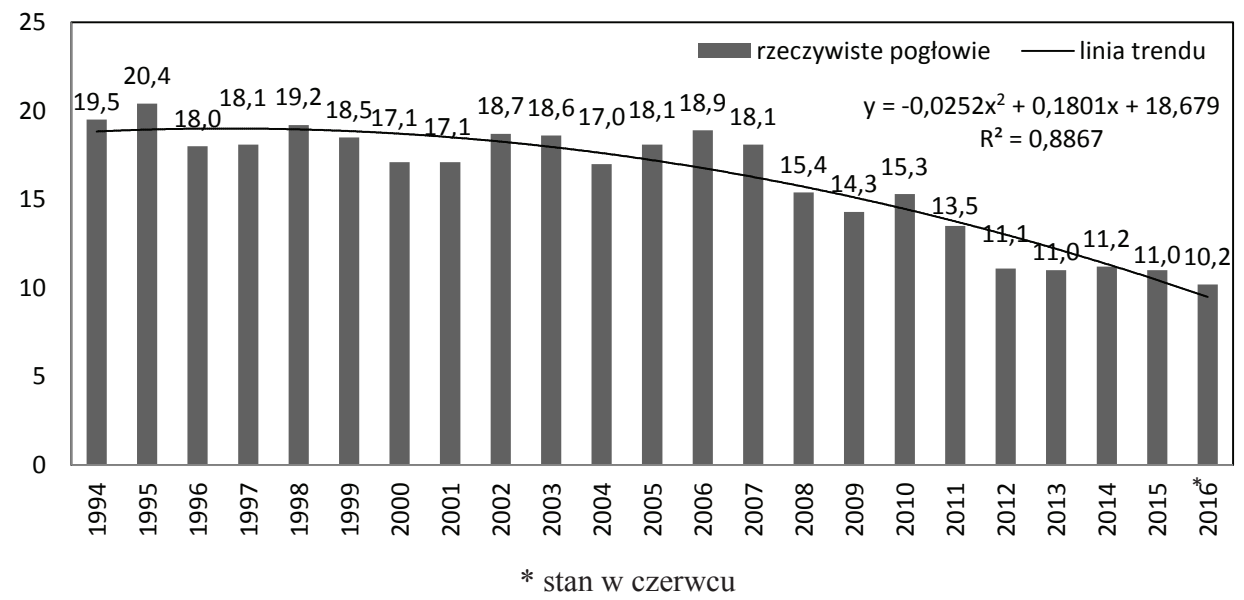

Rysunek 2. Zmiany pogłowia trzody chlewnej w Polsce w latach 1993-2016 Źródło: [GUS 1993-2016]. 
Tabela 4. Zmiany w pogłowiu trzody chlewnej w Polsce w latach 2007-2013

\begin{tabular}{lrrrr}
\hline Wyszczególnienie & \multicolumn{1}{c}{2007} & \multicolumn{1}{c}{2010} & \multicolumn{1}{c}{2012} & \multicolumn{1}{c}{2013} \\
\hline Pogłowie trzody chlewnej [tys. szt.] & 18100,00 & 15278,10 & 11581,30 & 11401,80 \\
Pogłowie trzody w stadach do 50 szt. & 6208,30 & 3936,47 & 2710,02 & 2674,25 \\
Pogłowie trzody w stadach 50-200 szt. & 6552,20 & 4161,43 & 2849,00 & 2937,23 \\
Pogłowie w stadach $\geq 200$ szt. & 5339,50 & 7180,71 & 6022,30 & 5790,32 \\
Zmniejszenie pogłowia w stadach do 200 szt. & - & $-4663,11$ & $-7201,48$ & $-7149,02$ \\
Wskaźnik zmniejszenia [\%] & 100,00 & $-36,50$ & $-56,43$ & $-56,02$ \\
Zwiększenie pogłowia w stadach > 200 szt. & - & 1841,21 & 682,80 & 450,82 \\
Wskaźnik zwiększenia [\%] & 100,00 & 34,50 & 12,78 & 8,44 \\
\hline
\end{tabular}

Źródło: [GUS 2014, 2015c].

sztuk. Po 2007 roku nastąpił systematyczny spadek pogłowia z 18,1 mln w 2007 roku do 10,2 mln sztuk w 2016 roku, czyli o 43,6\%. Obniżenie pogłowia dotyczyło głównie mniejszych stad - do 200 sztuk/gospodarstwo (tab. 4.). W latach 2007-2013 liczba świń zmniejszyła się o 6699 tys. szt., z tego w stadach do 200 szt. o 7149 tys., wzrosło zaś pogłowie trzody w stadach 200 szt. i większych o 450 tys. szt. Dane te potwierdzają wcześniejsze stwierdzenie o decydującym wpływie skali chowu na decyzje rolników.

Zmniejszenie pogłowia trzody chlewnej było zróżnicowane regionalnie. W 2009 roku największy udział w pogłowiu trzody chlewnej w Polsce miało województwo wielkopolskie $-17,2 \%$, następnie mazowieckie $(12,9 \%)$, kujawsko-pomorskie $(9,3 \%)$, podlaskie $(7,6 \%)$ i lubelskie $(7,4 \%)$. W tych województwach występowało prawie 55\% krajowego pogłowia. W latach następnych wystąpiły zmiany, w których wyniku w 2014 roku w pięciu województwach: wielkopolskim, kujawsko-pomorskim, łódzkim, mazowieckim i pomorskim znajdowało się ponad 70\% trzody chlewnej. Spadek dotknął wyraźnie województwa lubelskie, małopolskie, podkarpackie i świętokrzyskie, w których dominowały małe gospodarstwa [Ziętara, Mirkowska 2016].

Zmniejszenie pogłowia trzody chlewnej w Polsce miało negatywny wpływ na handel zagraniczny wieprzowiną i zwierzętami żywymi. Z danych zawartych w tabeli 5. wynika, że w latach 2009-2014 saldo handlu zagranicznego wieprzowiną, zarówno w ujęciu ilościowym, jak i wartościowym, było ujemne. Zdecydowanie niekorzystnie kształtowało się

Tabela 5. Handel zagraniczny wieprzowiną i zwierzętami żywymi

\begin{tabular}{|c|c|c|c|c|c|c|c|c|}
\hline \multicolumn{3}{|c|}{ Wyszczególnienie } & 2009 & 2010 & 2011 & 2012 & 2013 & 2014 \\
\hline \multicolumn{3}{|c|}{$\begin{array}{l}\text { Eksport [tys. t] } \\
\text { w ekwiwalencie mięsa }\end{array}$} & 336,0 & 418,0 & 500,1 & 585,5 & 705,6 & 619,7 \\
\hline \multicolumn{3}{|c|}{ Import [tys. t] } & 614,0 & 602,0 & 675,2 & 748,7 & 819,0 & 817,0 \\
\hline \multicolumn{3}{|c|}{ Saldo [ tys. t] } & $-278,0$ & $-184,0$ & $-175,1$ & $-163,2$ & $-113,4$ & $-197,3$ \\
\hline \multirow{2}{*}{\multicolumn{2}{|c|}{ Saldo [mln euro] }} & & $-524,5$ & $-336,0$ & $-338,7$ & $-323,9$ & $-283,4$ & $-446,8$ \\
\hline & & \multicolumn{7}{|c|}{ W tym handel trzodą chlewną (zwierzętami żywymi) [tys. szt.] w roku } \\
\hline & 2007 & 2008 & 2009 & 2010 & 2011 & 2012 & 2013 & 2014 \\
\hline Eksport & 434,0 & 418,8 & 442,2 & 274,4 & 102,8 & 138,8 & 107,98 & 84,6 \\
\hline Import & 401,7 & 1124,6 & 1997,5 & 2285,3 & 2667,6 & 3824,3 & 5138,8 & 5449,0 \\
\hline Saldo & 32,3 & $-709,8$ & $-1155,3$ & 2011,1 & $-2564,8$ & $-3685,5$ & $-5031,0$ & $-5364,4$ \\
\hline
\end{tabular}

Źródło: [„Analizy rynkowe” nr 32-43, 2014-2016, GUS 2014b, 2015c]. 
saldo handlu zagranicznego zwierzętami żywymi. 2007 rok był ostatnim, w którym to saldo było dodatnie i wynosiło 32,3 tys. sztuk. W kolejnych latach saldo było ujemne i zwiększało się z 709,8 tys. szt. w 2008 roku do 5364 tys. szt. w 2014 roku. W imporcie zdecydowanie przeważały (około $70 \%$ ) prosięta i warchlaki.

Tabela 6. Zmiany wielkości stad trzody i loch w badanych krajach w latach 2005-2013

\begin{tabular}{lrrrrc}
\hline Kraje & \multicolumn{2}{c}{ Trzoda [szt.] } & \multicolumn{2}{c}{ Lochy [szt.] } & Wskaźnik \\
\cline { 2 - 5 } & 2005 & 2013 & 2005 & 2013 & $2005=100$ \\
\hline Dania & 1500 & 3413 & 303 & 710 & $227 / 234$ \\
Francja & 353 & 727 & 100 & 149 & $206 / 149$ \\
Holandia & 1167 & 2208 & 280 & 480 & $189 / 171$ \\
Niemcy & 303 & 584 & 75 & 145 & $193 / 193$ \\
Szwecja & 649 & 1093 & 105 & 190 & $168 / 171$ \\
Wlk. Brytania & 424 & 3471 & 79 & 83 & $818 / 105$ \\
Polska & 25 & 41 & 4 & 6 & $164 / 150$ \\
\hline
\end{tabular}

Źródło: jak w tab. 1.

Wystąpiły również duże różnice w poziomie koncentracji chowu trzody chlewnej, określonym wielkością stada w gospodarstwach między Polską a innymi krajami. Odpowiednie liczby dotyczące lat 2005 i 2013 podano w tabeli 6. W 2005 roku średnia wielkość stada trzody chlewnej w Polsce wynosiła 25 szt., natomiast w Danii i Holandii wynosiła odpowiednio: 1500 i 1167 szt. i była odpowiednio: 60 i 45 razy większa. W pozostałych krajach zawarta była w przedziale od 303 szt. (Niemcy) do 649 szt. (Szwecja). W 2013 roku różnice te zwiększyły się. Przeciętne stado trzody w tym roku w Danii i Holandii było 83 i 54 razy większe niż w Polsce, gdzie wynosiło 41 szt. Zdecydowanie większe różnice wystąpiły w koncentracji loch. W 2005 roku średnie stado loch liczyło w Polsce 4 szt., natomiast w Danii i Holandii odpowiednio 303 i 280 loch. W pozostałych krajach średnia liczba loch w gospodarstwie zawarta była w przedziale od 75 szt. (Niemcy) do 105 szt. (Szwecja). W 2013 roku różnice się zwiększyły. Liczba loch w gospodarstwach duńskich i holenderskich wynosiła odpowiednio: 710 i 480 szt., natomiast w polskich zaledwie 6 sztuk. W Polsce najniższe było tempo wzrostu pogłowia trzody i loch. Wskaźniki wzrostu wynosiły odpowiednio: 164 i 150\%, natomiast w Danii 227 i 234\%.

\section{MINIMALNA WIELKOŚĆ POLSKICH GOSPODARSTW ZDOLNYCH DO KONKURENCJI I KONKURENCYJNYCH}

Informacje o wielkości gospodarstw i koncentracji produkcji zwierzęcej w gospodarstwach polskich i w badanych krajach skłaniają do postawienia pytania o minimalną wielkość polskich gospodarstw zdolnych do konkurencji i konkurencyjnych. Jako zdolne do konkurencji uznano gospodarstwa o wartości wskaźnika konkurencji $W k 3,(1=W k<2)$, natomiast konkurencyjne o wartości $W k 4,(W k \geq 2)$. Analizą konkurencyjności objęto gospodarstwa roślinne, $\mathrm{z}$ chowem bydła i trzody chlewnej jako dominujące w produkcji rolniczej. Odpowiednie liczby przedstawiono w tabelach 7.-11.

W tabeli 7. przedstawiono dane charakteryzujące gospodarstwa roślinne zdolne do konkurencji. Takimi okazały się polskie gospodarstwa zbożowe (typ 15) z klasy III, według 
Tabela 7. Minimalna wielkość gospodarstw roślinnych zdolnych do konkurencji i konkurencyjnych

\begin{tabular}{|c|c|c|c|c|}
\hline Kraje & $\begin{array}{c}\text { Klasa wielkości } \\
\text { ekonomicznej/Wk }\end{array}$ & $\begin{array}{c}\text { Powierzchnia UR } \\
\text { [ha] }\end{array}$ & $\begin{array}{c}\text { Udział zbóż w UR } \\
{[\%]}\end{array}$ & $\begin{array}{c}\text { Koszty ogółem } \\
\text { [tys. euro/ha] }\end{array}$ \\
\hline \multicolumn{5}{|c|}{ Minimalna wielkość gospodarstw roślinnych zdolnych do konkurencji } \\
\hline \multicolumn{5}{|c|}{ Gospodarstwa zbożowe (typ 15) } \\
\hline Polska & $\mathrm{III} / 1,87$ & 59,38 & 71,36 & 0,66 \\
\hline Węgry & $\mathrm{III} / 1,80$ & 68,09 & 64,24 & 0,62 \\
\hline Czechy & $\mathrm{III} / 1,21$ & 53,50 & 66,49 & 0,82 \\
\hline Niemcy & $\mathrm{V} / 1,44$ & 219,23 & 64,43 & 1,34 \\
\hline \multicolumn{5}{|c|}{ Gospodarstwa z różnymi uprawami ( typ 16) } \\
\hline Polska & $\mathrm{III} / 1,63$ & 34,23 & 53,30 & 1,01 \\
\hline Węgry & $\mathrm{III} / 1,96$ & 50,28 & 35,25 & 0,85 \\
\hline Czechy & IV/1,67 & 68,21 & 51,07 & 1,17 \\
\hline Niemcy & IV $/ 1,23$ & 63,77 & 47,29 & 1,62 \\
\hline \multicolumn{5}{|c|}{ Minimalna wielkość konkurencyjnych gospodarstw roślinnych } \\
\hline \multicolumn{5}{|c|}{ Gospodarstwa zbożowe (typ 15) } \\
\hline Polska & $\mathrm{IV} / 2,51$ & 109,6 & 68,0 & 0,67 \\
\hline Węgry & $\mathrm{IV} / 2,09$ & 127,8 & 63,5 & 0,66 \\
\hline Niemcy & $\mathrm{VI} / 2,58$ & 1004,2 & 64,4 & 1,45 \\
\hline \multicolumn{5}{|c|}{ Gospodarstwa z różnymi uprawami (typ 16) } \\
\hline Polska & IV/202 & 67,41 & 55,62 & 0,93 \\
\hline Węgry & $\mathrm{IV} / 2,48$ & 78,56 & 44,88 & 0,92 \\
\hline Czechy & $\mathrm{V} / 2,20$ & 176,45 & 49,64 & 1,33 \\
\hline Niemcy & $\mathrm{V} / 2,17$ & 110,75 & 48,33 & 2,03 \\
\hline
\end{tabular}

Źródło: [Ziętara, Zieliński 2016].

wielkości ekonomicznej (25-50 tys. euro SO) określone jako średnio małe. Zdolnościami konkurencyjnymi wykazały się również tej samej klasy gospodarstwa węgierskie i czeskie. Natomiast takimi zdolnościami wykazały się niemieckie gospodarstwa zbożowe z klasy V określone jako duże o wartości SO z przedziału 100-500 tys. euro. Powierzchnia użytków rolnych w gospodarstwach polskich, węgierskich i czeskich była zbliżona, zawarta w przedziale od 53,5 ha UR (Czechy) do 68,09 ha UR (Węgry). Powierzchnia niemieckich gospodarstw zbożowych zdolnych do konkurencji wynosiła 219,23 ha UR i była ponadtrzykrotnie większa niż gospodarstw polskich. Polskie gospodarstwa zbożowe wyróżniały się wyższym udziałem zbóż w powierzchni UR $(71,36 \%)$. W pozostałych gospodarstwach udział zbóż był niższy, wynosił około 65\%. Poziom intensywności produkcji określony kosztami ogółem w przeliczeniu na 1 ha UR w gospodarstwach niemieckich wynosił 1,34 tys. euro/ha i był dwukrotnie wyższy niż w gospodarstwach polskich.

Powierzchnia zdolnych do konkurencji gospodarstw roślinnych z różnymi uprawami (typ 16) była zdecydowanie mniejsza niż zbożowych. W gospodarstwach polskich i węgierskich odpowiednio mniej: o 42 i $26 \%$, a niemieckich o $71 \%$. W czeskich była większa o $27 \%$. Gospodarstwa polskie i węgierskie pod względem wielkości ekonomicznej były średnio małe (klasa III), natomiast czeskie i niemieckie średnio duże (klasa IV). Gospodarstwa tej grupy charakteryzowały się niższym udziałem zbóż w powierzchni UR, od 35,25\% (Czechy) do 53,30\% (Polska), i wyższym poziomem intensywności, średnio o 38\%. 
W tabeli 7. przedstawiono minimalne wielkości konkurencyjnych gospodarstw roślinnych z Polski i badanych krajów. Polskie i węgierskie gospodarstwa zbożowe (typ 15) pod względem wielkości ekonomicznej mieściły się w klasie IV (średnio duże) o wartości z przedziału 50-100 tys. euro SO i powierzchni odpowiednio: 109,6 i 127,8 ha UR. Gospodarstwa niemieckie były reprezentowane przez klasę VI (bardzo duże) o wartości 500 tys. euro SO i więcej i powierzchni 1004,2 ha UR. Udział zbóż w powierzchni UR był zbliżony w badanych gospodarstwach, zawarty w przedziale $64-68 \%$ i był zgodny z zaleceniami agrotechnicznymi. Ponadto poziom intensywności produkcji w gospodarstwach niemieckich wynosił 1,45 tys. euro/ha i był ponaddwukrotnie wyższy niż w gospodarstwach polskich i węgierskich.

Wielkość ekonomiczna polskich i węgierskich konkurencyjnych gospodarstw z różnymi uprawami (typ 16) mieściła się, podobnie jak w typie 15, w klasie IV, jednak ich powierzchnia była o około 38\% mniejsza, zrekompensowana o 39\% wyższym poziomem intensywności produkcji. Gospodarstwa czeskie i niemieckie mieściły się w V (duże) klasie wielkości ekonomicznej. Ich powierzchnia była większa i wynosiła odpowiednio: 176,5 i 110,75 ha UR. Poziom intensywności w gospodarstwach czeskich był o 44\%, a niemieckich o $119 \%$ wyższy niż w polskich i węgierskich. Udział zbóż w tym typie gospodarstw był niższy niż w typie 15 i zawierał się w przedziale $45-55 \%$.

W tabeli 8. przedstawiono dane charakteryzujące minimalne wielkości polskich gospodarstw mlecznych zdolnych do konkurencji i konkurencyjnych. Ich wielkość została określona liczbą utrzymywanych krów w gospodarstwie. Różnice między latami 2010 i 2013 odnośnie liczby krów były niewielkie. Postęp dotyczył wydajności mlecznej krów i cen mleka, natomiast pewien regres wyników ekonomicznych. Z przedstawionych danych wynika, że zdolności konkurencyjne wykazywały gospodarstwa utrzymujące około 25 krów o wydajności około 6 tys. kg w przeliczeniu na krowę rocznie. Świadczą o tym dodatni

Tabela 8. Skala produkcji i efekty ekonomiczne gospodarstw mlecznych w latach 2010 i 2013

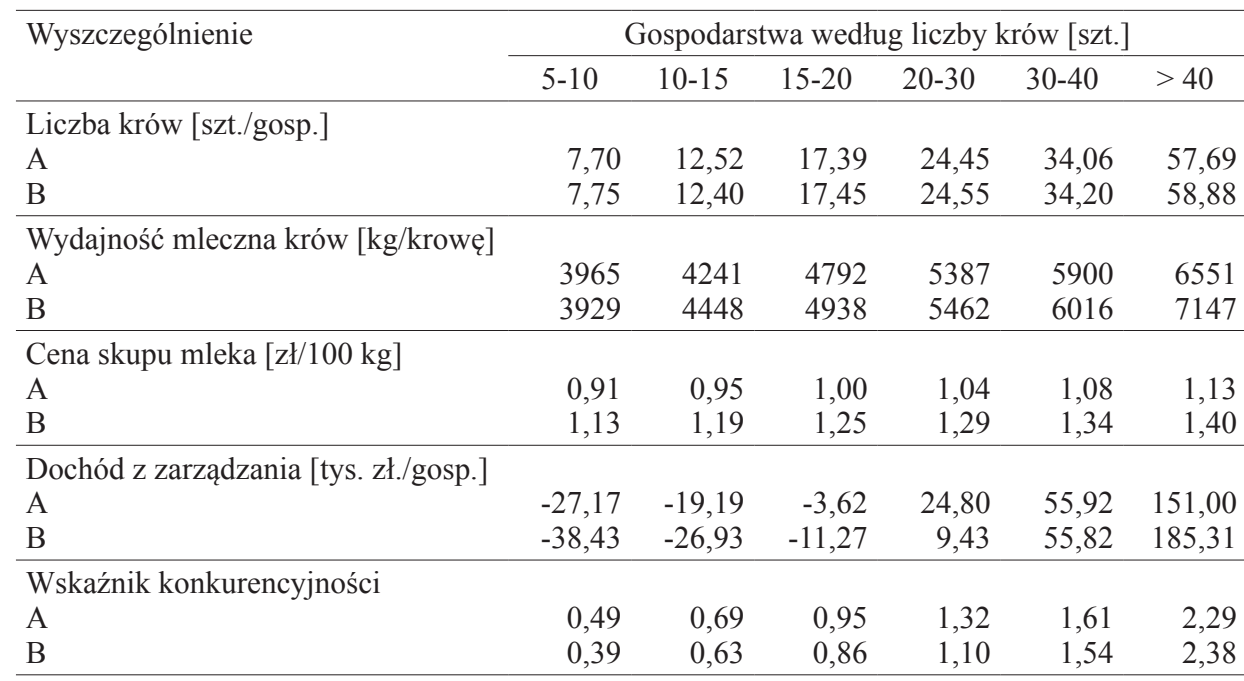

A-rok 2010; B - rok 2013;

Źródło: [Goraj i in. 2012, 2015]. 
dochód z zarządzania ${ }^{5}$ i wskaźnik konkurencyjności wyższy od 1. W pełni konkurencyjne okazały się gospodarstwa utrzymujące około 60 krów mlecznych o wydajności około 7 tys. kg na krowę rocznie. Zaobserwowano dodatni związek między skalą produkcji mleka a wydajnością mleczną i cenami zbytu mleka. Różnica między skrajnymi klasami w 2013 roku w wydajności mlecznej wynosiła $82 \%$, a w cenie zbytu $24 \%$. Dane te potwierdzają tezę, że skala produkcji ściśle wiąże się z profesjonalizacją i efektywnością produkcji.

W tabelach 9., 10. i 11. przedstawiono dane charakteryzujące polskie gospodarstwa trzodowe zdolne do konkurencji i konkurencyjne. Minimalna wielkość gospodarstw trzodowych, określona liczbą utrzymywanych loch, zdolnych do konkurencji wynosiła około 35 loch. Gospodarstwa o tej skali uzyskiwały dodatni dochód z zarządzania i wartość wskaźnika konkurencji ( $W k 3$ ) 1,19. Gospodarstwa te użytkowały 36,84 ha UR, a roczna sprzedaż żywca wynosiła $62,16 \mathrm{t}$. W pełni konkurencyjne były gospodarstwa utrzymujące 151 loch i sprzedające 245,2 t żywca. Analiza zdolności rozwojowych gospodarstw według liczby sprzedanych tuczników wykazała, że zdolności konkurencyjne miały gospodarstwa sprzedające rocznie około 62 t żywca, co odpowiada 587 tucznikom o średniej wadze 105 $\mathrm{kg}$. Wartość $W k 3$ wynosiła w nich zaledwie 1,07. Natomiast konkurencyjne gospodarstwa tego typu powinny sprzedawać około 2500 tuczników rocznie. Wskaźnik Wk4 w takim gospodarstwie osiągnie wartość 2,28.

Tabela 9. Efektywność polskich wyspecjalizowanych gospodarstw trzodowych w zależności od liczby utrzymywanych loch w gospodarstwie w 2014 roku

\begin{tabular}{lrrrrrr}
\hline Wyszczególnienie & \multicolumn{6}{c}{ Liczba loch w gospodarstwie } \\
\cline { 2 - 7 } & $10-20$ & $20-30$ & $30-40$ & $40-50$ & $50-80$ & \multicolumn{1}{c}{$\geq 80$} \\
\hline Powierzchnia UR [ha] & 21,03 & 27,91 & 36,84 & 39,48 & 44,26 & 78,23 \\
Liczba loch [szt.] & 14,57 & 24,58 & 34,18 & 44,03 & 61,40 & 151,13 \\
Sprzedaż żywca [t/gospodarstwo] & 30,20 & 47,75 & 62,16 & 81,53 & 113,31 & 245,20 \\
Cena zbytu [zł/kg] & 4,61 & 4,71 & 4,86 & 4,88 & 5,01 & 4,96 \\
Dochód z zarządzania [tys. zł] & $-19,90$ & $-11,90$ & 15,79 & 57,75 & 85,34 & 136,13 \\
Wskaźnik konkurencyjności Wk4 & 0,70 & 0,85 & 1,19 & 1,66 & 1,93 & 2,13 \\
\hline
\end{tabular}

Źródło: [Goraj i in. 2016]

Tabela 10. Efektywność polskich wyspecjalizowanych gospodarstw trzodowych w zależności od liczby sprzedanych tuczników w 2014 roku

\begin{tabular}{lrrrrrr}
\hline Wyszczególnienie & \multicolumn{6}{c}{ Liczba sprzedanych tuczników } \\
\cline { 2 - 7 } & $80-120$ & $120-200$ & $200-400$ & $400-700$ & $700-1000$ & $\geq 1000$ \\
\hline Powierzchnia UR [ha] & 12,39 & 17,22 & 24,17 & 32,36 & 38,25 & 62,57 \\
Sprzedaż żywca [t/gospodarstwo] & 12,53 & 19,29 & 43,07 & 61,69 & 93,21 & 263,08 \\
Cena zbytu [zł/kg] & 4,62 & 4,65 & 4,70 & 4,82 & 4,88 & 5,13 \\
Dochód z zarządzania [tys. zł] & $-28,38$ & $-32,41$ & $-22,17$ & 5,97 & 43,06 & 134,89 \\
Wskaźnik konkurencyjności Wk4 & 0,45 & 0,47 & 0,69 & 1,07 & 1,50 & 2,28 \\
\hline
\end{tabular}

Źródło: jak w tab. 9.

5 Dochód z zarządzania - różnica między dochodem z gospodarstwa a kosztami własnych czynników produkcji (ziemi, pracy i kapitału). 
Tabela 11. Efektywność polskich wyspecjalizowanych gospodarstw trzodowych w zależności od liczby sprzedanych prosiąt w latach 2013 i 2014

\begin{tabular}{lrrrrr}
\hline Wyszczególnienie & \multicolumn{4}{c}{ Liczba sprzedanych prosiąt } \\
\cline { 2 - 6 } & \multicolumn{3}{c}{2013} & \multicolumn{3}{c}{2014} \\
\cline { 2 - 6 } & 9,200 & $200-500$ & $500-1200$ & $<200$ & $500-1200$ \\
\hline Powierzchnia UR [ha] & 15,93 & 20,28 & 9,64 & 20,07 \\
Liczba loch [szt.] & 6,99 & 19,14 & 43,58 & 9,49 & 44,26 \\
Liczba odchowanych prosiąt & 18,71 & 18,15 & 20,24 & 14,47 & 18,91 \\
Cena zbytu [zł/kg] & 8,40 & 8,50 & 8,36 & 7,85 & 7,68 \\
Dochód z zarządzania [tys. zł] & $-37,21$ & $-23,03$ & 14,45 & $-32,00$ & 4,61 \\
Wskaźnik konkurencyjności $W k 4$ & 0,24 & 0,65 & 1,21 & 0,34 & 0,94 \\
\hline
\end{tabular}

Źródło: [Goraj i in. 2015, 2016].

W tabeli 11. przedstawiono wyniki gospodarstw nastawionych na produkcję prosiąt. Dostępne dane dotyczyły lat 2013 i 2014 i rocznej sprzedaży prosiąt z przedziału 5001200 sztuk rocznie. Gospodarstwa z tą wielkością sprzedanych prosiąt wykazały się zdolnością do konkurencji, osiągając wartość Wk3 odpowiednio: 1,21 i 0,94 w badanych latach. Utrzymywały one około 44 loch. Szacunki wskazują, że gospodarstwa tego typu, aby być w pełni konkurencyjnymi, powinny utrzymywać powyżej 100 loch i sprzedawać powyżej 2500 prosiąt rocznie. Podane wielkości trzodowych gospodarstw zdolnych do konkurencji i konkurencyjnych bardzo różniły się od wielkości przeciętnych w naszym kraju, są jednak niższe od średnich wielkości gospodarstw mlecznych i trzodowych w analizowanych krajach Europy Zachodniej.

\section{SPOŁECZNE, ŚRODOWISKOWE I ADMINISTRACYJNE BARIERY ROZWOJU ROLNICTWA, SZCZEGÓLNIE PRODUKCJI ZWIERZĘCEJ}

Produkcja towarowa rolnictwa jest adekwatnym miernikiem poziomu produkcji rolniczej. Jej struktura zdominowana jest przez produkcję zwierzęcą, której udział w 2000 roku wynosił 62,6\%. W kolejnych latach ulegał niewielkiemu obniżeniu i w 2014 roku wynosił 59,3\%. Dominujący był udział żywca, który w tym roku wynosił $34,2 \%$, w tym trzodowy i drobiowy odpowiednio: 14,1 i 13,7\%. Udział mleka wynosił 18,8\% [GUS 2015c]. O efektywności produkcji zwierzęcej decydują koszty produkcji. Wśród nich w ostatnich kilku latach znaczącą rolę odgrywają koszty związane z poprawą dobrostanu zwierząt. Jest to efekt wzrostu zainteresowania przez społeczeństwo warunkami utrzymania zwierząt. Chodzi nie tylko o sposób chowu zwierząt, lecz także o powierzchnię przypadającą na jedno zwierzę i wentylację pomieszczeń. Poprawa dobrostanu zwierząt wiąże się z ponoszeniem dodatkowych kosztów. Nie wszyscy producenci wykazują do tego gotowość. Nie zawsze uświadamiają sobie, że poprawa dobrostanu zwierząt prowadzi do poprawy ich zdrowotności, dłuższego ich użytkowania i wzrostu efektywności produkcji. Z tych stwierdzeń wynika jednoznaczny wniosek: poprawa dobrostanu utrzymywanych zwierząt nie powinna być postrzegana jako dodatkowe obciążenie, lecz jako inwestycja sprzyjająca poprawie efektywności produkcji w dłuższym czasie.

W ostatnich kilkunastu latach zaobserwowano zwiększenie aktywności organizacji występujących w obronie praw zwierząt. Tego typu działania, mimo że podejmowane są ze szlachetnych pobudek, wywołują w społeczeństwie nastroje niechęci do producentów rolnych prowadzących produkcję zwierzęcą. Wskazują także na uciążliwości dla otoczenia 
(odory) związane z chowem zwierząt. Znajduje to wyraz w protestach mieszkańców wsi przeciwko inwestycjom w budynki inwentarskie o większej koncentracji, umownie określane jako fermy typu przemysłowego - industrialnego ${ }^{6}$. Dotyczy to głównie budynków do chowu trzody chlewnej i drobiu, a w mniejszym stopniu chowu bydła.

Należy poważnie brać pod uwagę, że prowadzenie produkcji zwierzęcej, zwłaszcza produkcji mleka i żywca trzodowego, należy do najbardziej uciążliwych prac w rolnictwie (ciągłość pracy, odory). Z tego powodu grupa tych producentów wymaga społecznej akceptacji i ochrony. Hodowca zwierząt - producent rolny niezależnie od wymogów dobrostanu zwierząt i środowiska musi uwzględniać dobro własnej rodziny przez uzyskanie odpowiedniego poziomu dochodu zapewniającego byt rodzinie i rozwój gospodarstwa zgodnie z tempem wzrostu gospodarki narodowej. Spełnienie tych warunków wiąże się niezależnie od innych czynników z koniecznością ciągłego wzrostu skali produkcji. Wzrost skali produkcji zwierzęcej w gospodarstwach prowadzi do sytuacji konfliktowych na terenach wiejskich, między rolnikami a ludnością nierolniczą. Chów trzody chlewnej i drobiu należy do działalności produkcji zwierzęcej stosunkowo luźno związanych z ziemią. Może być prowadzony na większą skalę bez użytków rolnych. Problemem będącym źródłem konfliktów jest zagospodarowanie odchodów. Te sytuacje konfliktowe o charakterze społecznym stanowią istotną barierę rozwoju gospodarstw.

Zagospodarowanie odchodów, szczególnie trzody chlewnej i drobiu utrzymywanych w tzw. systemie przemysłowym, postrzegane jest jako zagrożenie środowiskowe. Ważnym wskaźnikiem oceny różnych systemów chowu zwierząt z punktu widzenia środowiska jest zużycie wody. Spośród trzech wyróżnianych systemów chowu zwierząt: pastwiskowego, mieszanego i przemysłowego w powszechnym odczuciu za najbardziej przyjazny dla środowiska uznaje się system pastwiskowy. Wyniki przeprowadzonych badań, przedstawionych w tabeli 12., przeczą tym opiniom. Badania dotyczyły zużycia wody (pośredniego i bezpośredniego) w przeliczeniu na jednostkę produktu zwierzęcego. Pod uwagę wzięto zużycie wody w litrach na kg przyrostu żywca drobiowego, wieprzowego, wołowego i baraniego oraz jaj i mleka. Z przedstawionych danych wynika, że najmniejsze zużycie wody wystąpiło w systemie przemysłowym. W produkcji żywca drobiowego, baraniego i jaj zużycie wody w systemie przemysłowym było około $66 \%$ niższe niż w systemie pastwiskowym. W produkcji żywca wołowego zużycie to było niższe o 53\%. Jedynie w produkcji mleka zużycie wody na kg mleka w systemie przemysłowym było podobne jak w systemie pastwiskowym.

Niezależnie od wymienionych występują bariery typu ideologicznego polegające na nierównym traktowaniu przedsiębiorstw rolnych ze względu na formę prawną. Zgodnie z art. 23 Konstytucji RP podstawę ustroju rolnego w rolnictwie polskim stanowią gospodarstwa rodzinne. Jednak treść tego artykułu nie upoważnia do dyskryminacji innych form prawnych przedsiębiorstw rolniczych (rolnicze spółdzielnie produkcyjne i spółki prawa handlowego), przejawiającej się ograniczaniem ich prawa do rozwoju (inwestowania i zwiększania skali produkcji)7.

Dużymi utrudnieniami w procesie inwestowania w budynki inwentarskie są bariery administracyjne wynikające $\mathrm{z}$ :

\footnotetext{
Pojęcie produkcji (industrialnej) w odniesieniu do rolnictwa nie ma obiektywnego charakteru. Produkcja rolnicza oparta jest na siłach natury. Prawdziwymi producentami są rośliny i zwierzęta. Rolą człowieka - producenta rolnego jest zapewnienie im odpowiednich warunków wzrostu i rozwoju. Twierdzenie, że stosowanie w rolnictwie przemysłowych środków produkcji (nawozów mineralnych, chemicznych środków ochrony roślin i pasz pochodzenia przemysłowego) przesądza o industrialnym charakterze produkcji rolniczej jest nieuzasadnione. W odniesieniu do chowu zwierząt (drobiu, trzody chlewnej) prowadzonego w pomieszczeniach zamkniętych z kontrolowanym środowiskiem występują pewne analogie do produkcji przemysłowej pod względem metod produkcji. Jednak procesu produkcji w tych warunkach nie można utożsamiać z przemysłowym.

7 Wymienione podmioty zostały pozbawione prawa do zakupu gruntów rolnych z ZWRSP [Ustawa z 11 kwietnia 2003 r. o kształtowaniu ustroju rolnego z dalszymi zmianami. Dz.U.2016.2052].
} 
Tabela 12. Zużycie wody (bezpośrednie i pośrednie) w różnych systemach chowu zwierząt

\begin{tabular}{lrrr}
\hline \multirow{2}{*}{ Wyszczególnienie } & \multicolumn{3}{c}{ Żużycie wody $[1 / \mathrm{kg}]$ w systemie chowu } \\
\cline { 2 - 4 } & pastwiskowym & mieszanym & przemysłowym \\
\hline Drób & 9371 & 4987 & 2872 \\
Wskaźnik & 100 & 53 & 31 \\
\hline Żywiec wieprzowy & 8723 & 6227 & 5224 \\
Wskaźnik & 100 & 71 & 60 \\
\hline Żywiec wołowy & 21829 & 6227 & 5224 \\
Wskaźnik & 100 & 71 & 60 \\
\hline Żywiec barani & 16311 & 8335 & 5623 \\
Wskaźnik & 100 & 51 & 34 \\
\hline Jaja & 7644 & 3863 & 38 \\
Wskaźnik & 199 & 50 & 1207 \\
\hline Mleko & 1191 & 956 & 101 \\
Wskaźnik & 100 & 80 &
\end{tabular}

Źródło: [Florek 2016].

- braku planów zagospodarowania przestrzennego w większości gmin,

- blokowania inwestycji budowanych na ternach wiejskich przez ludność nierolniczą, w sytuacji braku jednoznacznych uregulowań prawnych,

- nadmiernego formalizmu prawa i niepewności,

- braku jednoznacznych uregulowań prawnych w zakresie poziomu intensywności produkcji zwierzęcej [Lesiak 2016].

Przy opracowaniu planów zagospodarowania przestrzennego należy uwzględnić stanowisko ministrów rolnictwa 6 krajów, w tym Polski przyjęte 19.09.2014 roku [Komunikat... 2014], w którym zapisano:

- konieczne jest ograniczenie wykorzystania gruntów rolnych na cele nierolnicze,

- własność i długoterminowa dzierżawa stanowią najlepsze przesłanki zrównoważonego gospodarowania,

- redukcja pozarolniczego wykorzystania gruntów rolnych,

- zabezpieczenie produkcji żywności, (...) przy wykorzystaniu terenów rolniczych zapewnić priorytet produkcji żywności, podnosić wydajność zgodnie z możliwościami ekosystemów rolniczych przy trwałym zabezpieczeniu funkcji produkcyjnych ziemi,

- wspieranie przyjaznych dla środowiska i zasobooszczędnych sposobów gospodarowania (gleba, woda),

- zabezpieczenie przyszłości przez zrównoważony wzrost (polepszanie żyzności gleb, ochrona wód i klimatu).

\section{WNIOSKI}

1. Szybsze tempo wzrostu kosztów pracy w gospodarce narodowej i cen środków produkcji dla rolnictwa od cen zbytu produktów rolnych powoduje spadek jednostkowej opłacalności produkcji rolniczej i zmusza rolników do zwiększania skali produkcji. 
2. Rosnące wymogi handlu i przetwórstwa rolnego w zakresie jakości, wielkości i ciągłości dostaw produktów wywołują konieczność wzrostu skali produkcji w przedsiębiorstwach rolniczych.

3. Wzrost skali (wielkości) przedsiębiorstw wiąże się ze spadkiem ich liczby kosztem podmiotów bez zdolności rozwojowych (o małej skali).

4. Wzrost udziału ludności nierolniczej na terenach wiejskich prowadzi do zmiany relacji ludności nierolniczej do rolniczej i w efekcie do konfliktów, których rozwiązanie nie powinno ograniczać możliwości rozwoju przedsiębiorstw rolnych.

5. W polskim rolnictwie występuje duża różnica w potencjale produkcyjnym między przedsiębiorstwami zdolnymi do rozwoju i bez tych zdolności.

6. Występuje bardzo duży dystans między wielkością gospodarstw i stopniem koncentracji produkcji zwierzęcej w Polsce i w krajach Europy Zachodniej.

7. W Polsce profesjonalnie prowadzone gospodarstwa rolne o odpowiedniej skali mają zdolności konkurencyjne, szczególnie te z produkcją zwierzęcą.

8. Podstawową przyczyną spadku pogłowia trzody chlewnej w Polsce w ostatnich latach, oprócz spadku opłacalności w przedsiębiorstwach o małej skali, są bariery administracyjne związane $\mathrm{z}$ inwestowaniem w nowe chlewnie o większej koncentracji.

9. Najsłabszym ogniwem w produkcji żywca wieprzowego jest produkcja prosiąt. Stąd potrzeba zdecydowanego wsparcia tej działalności.

10. Podstawowym warunkiem odbudowy pogłowia trzody chlewnej w Polsce jest podejście systemowe oparte na specjalizacji gospodarstw w zakresie produkcji prosiąt i tuczu, integracji poziomej między producentami i pionowej między producentami żywca i przedsiębiorstwami przetwórczymi.

11. Konieczne jest wykorzystanie technologii produkcji umożliwiających redukcję odorów, m.in. przez łączenie chowu trzody z produkcją biogazu.

12. Przykłady przedsiębiorstw z chowem trzody chlewnej z Danii, Holandii, Wielkiej Brytanii i Niemiec wskazują na możliwość osiągnięcia w przedsiębiorstwach rolnych równowagi między celami ekonomicznymi, społecznymi i środowiskowymi. Poziom koncentracji produkcji trzody chlewnej w tych krajach jest od 10 do 85 razy wyższy niż w Polsce, mimo dwu- a nawet trzykrotnie większego zagęszczenia ludności niż w Polsce.

13. Tzw. przemysłowe systemy chowu zwierząt wbrew potocznym opiniom są bardziej zasobooszczędne w zakresie zużycia wody niż systemy tradycyjne (pastwiskowy i mieszany).

\section{LITERATURA}

„Analizy rynkowe“ nr 39-43, 2014-2016: Handel zagraniczny produktami rolno-spożywczymi-stan i perspektywy, IERiGŻ-PIB, Warszawa.

Biswanger Hans Christoph, 2011: Spirala wzrostu, pieniądz, energia i kreatywność $w$ dynamice procesów rynkowych, ZYSK I S-KA, Poznań, s. 213.

GUS, 1993-2016: Rocznik statystyczny rolnictwa i obszarów wiejskich, Warszawa.

GUS, 2014: Zwierzęta gospodarskie w 2013 r. Warszawa.

GUS, 2015a: Charakterystyka gospodarstw rolniczych w 2013 r., Warszawa.

GUS, 2015b: Maty rocznik statystyczny, Warszawa.

Florek Mariusz, 2016: Funkcje i wykorzystanie wody w produkcji podstawowej i przetwórstwie żywności pochodzenia zwierzęcego. „Przegląd Hodowlany”, nr 6, s. 7.

Goraj Lech, Monika Bocian, Dariusz Osuch, Adam Smolik, 2009-2016: Parametry techniczno-ekonomiczne wedlug grup gospodarstw rolnych uczestniczacych $w$ polskim FADN $w$ latach 2008-2015, IERIGŻ-PIB. 
Kleinhanss Werner, 2015: Konkurencyjność głównych typów gospodarstw rolniczych w Niemczech, „Zagadnienia Ekonomiki Rolnej”, nr 1/2015, s. 26-27.

Komunikat ministrów rolnictwa Niemiec, Luksemburga, Holandii, Austrii, Polski i Szwajcarii w dniu 19 września 2014 r. Zachowanie gruntów rolnych, www.newsd.admin.ch/newsed/message/ attchments.41408.pdf.

Lesiak Danuta, 2016: Bariery prawne dla rozwoju produkcji trzody chlewnej w Polsce, [w] Perspektywy $i$ wyzwania dla rozwoju produkcji trzody chlewnej w Polsce - Unijne i krajowe bariery o charakterze formalno-prawnym, Krajowy Związek Pracodawców i Producentów Trzody Chlewnej, Warszawa, s. 110-112.

Statistisches Jahrbuch über Ernährung, 2015: Landwirtschaft und Forsten, Landwirtschaftsverlag. Ustawa z 11 kwietnia 2003 r. o ksztaltowaniu ustroju rolnego z dalszymi zmianami, Dz.U.2016.2052. Woś Augustyn, 2003: Konkurencyjność potencjalna polskiego rolnictwa, [w] Źródła przewag konkurencyjnych przedsiębiorstw w agrobiznesie, Wydawnictwa AR w Lublinie, s. 9.

Ziętara Wojciech, Marcin Adamski, Henryk Grodzki, 2013: Polskie gospodarstwa mleczne na tle wybranych krajów, Raport Programu Wieloletniego IERiGZ-PIB, nr 86, Warszawa.

Ziętara Wojciech, Marcin Adamski, 2016: Uwarunkowania opłacalności produkcji mleka i wołowiny w polskich gospodarstwach, [w] Produkcja mleka i wołowiny - teraźniejszość i przyszłość, Uniwersytet Rolniczy im. Hugona Kołłątaja w Krakowie, Instytut Nauk o Zwierzętach, Zakład Hodowli Bydła. Kraków, s. 100-119.

Ziętara Wojciech, Zofia Mirkowska, 2016: Uwarunkowania efektywności chowu trzody chlewnej w gospodarstwach polskich, Maszynopis w Zakładzie Ekonomiki Gospodarstw Rolnych, IERiGŻ-PIB, Warszawa.

Ziętara Wojciech, Marek Zieliński, 2016: Polskie gospodarstwa roślinne na tle wybranych krajów, „Zagadnienia Ekonomiki Rolnej”, nr 2, s. 72-95.

\section{Wojciech Ziętara \\ FACTORS OF DEVELOPMENT OF AGRICULTURAL ESTABLISHMENTS ORIENTED TOWARDS ANIMAL PRODUCTION UNDER CONDITIONS OF COMPETITION AND GLOBALIZATION}

\section{Summary}

The study presents economic, social, environmental and administrative factors influencing the development of agricultural enterprises, mainly the ones breeding pigs and cattle. Economic and organizational factors inducing agricultural companies to increase the scale of production are shown. The economic factors are associated with faster growth of labor costs in the national economy and the prices of means of agricultural production than of the sales prices of agricultural products. The organizational factors are connected with the growing requirements of trade companies and agricultural processing in terms of size, quality and timely deliveries. The increase in the scale of production can lead to excessive burden on the environment and growth of odor nuisance to the non-agricultural population in rural areas. As a result, it can cause social conflict situations. In addition, there are administrative barriers hindering the implementation of construction projects related to the development of animal production.

Adres do korespondencji: Prof. dr hab. Wojciech Ziętara Instytut Ekonomiki Rolnictwa i Gospodarki Żywnościowej - PIB Zakład Ekonomiki Gospodarstw Rolnych ul. Świętokrzyska 20, 00-002 Warszawa, tel. (22) 5054584 e-mail: wojciech.zietara@ierigz.waw.pl 